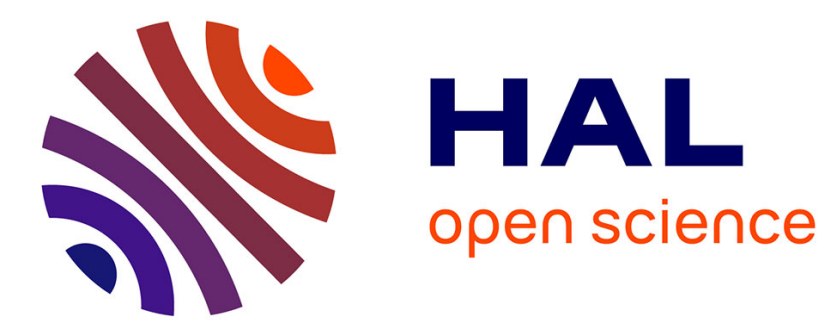

\title{
Water and Food in the Twenty-First Century
}

Ghislain de Marsily, Rodrigo Abarca-Del-Rio

\section{- To cite this version:}

Ghislain de Marsily, Rodrigo Abarca-Del-Rio. Water and Food in the Twenty-First Century. Surveys in Geophysics, 2016, 37 (2), pp.503-527. 10.1007/s10712-015-9335-1 . hal-01205954

\section{HAL Id: hal-01205954 https://hal.sorbonne-universite.fr/hal-01205954}

Submitted on 28 Sep 2015

HAL is a multi-disciplinary open access archive for the deposit and dissemination of scientific research documents, whether they are published or not. The documents may come from teaching and research institutions in France or abroad, or from public or private research centers.
L'archive ouverte pluridisciplinaire HAL, est destinée au dépôt et à la diffusion de documents scientifiques de niveau recherche, publiés ou non, émanant des établissements d'enseignement et de recherche français ou étrangers, des laboratoires publics ou privés. 
Surv Geophys, DOI 10.1007/s10712-015-9335-1

Received: 24 March 2015/ Accepted: 4 August 2015

\title{
Water and Food in the $21^{\text {st }}$ century Ghislain de Marsily ${ }^{1,2}$, Rodrigo Abarca-del-Río ${ }^{3}$
}

1 : Sorbonne Universités, UPMC Univ. Paris 06, CNRS, EPHE, UMR 7619 Metis, 4, place Jussieu, 75005 Paris, France

2 : French Academy of Sciences, 23 quai de Conti, 75006 Paris, France.

E-mail: gdemarsily@aol.com, Corresponding author.

3 : Departamento de Geofísica (DGEO), Facultad de Ciencias Físicas y Matemáticas, Universidad de Concepción, Concepción, Chile. E-mail: rodrigo.abarcadelrio@udec.cl.

\begin{abstract}
In 2000, the World population was 6.2 billion people; it reached 7 billion in 2012, and is expected to reach 9.5 billion ( \pm 0.4) in 2050, 11 billion ( \pm 1.5 ) in 2100, according to the 2012 UN projections (Gerland et al. 2014). The trend after 2100 is still one of global demographic growth, but after 2060, Africa is the only continent where the population would still increase. The amount of water consumed annually to produce the food necessary to meet the needs of the populations varies greatly between countries, from about 600 to $2500 \mathrm{~m}^{3} / \mathrm{y}$ per capita (Zimmer 2013), depending on their wealth, their food habits, and the percentage of food waste they generate (on average, $30 \%$ of the food produced is wasted). In 2000, the total food production was on the order of 3300 million tons (in cereal equivalents). In 2014, it is estimated that about 0.8 billion inhabitants of the planet suffer from hunger (FAO 2014) and do not get the nutrition they need to be in good health or, in the case of children, to grow properly (both physically and intellectually). This food deficit was on the order of 40 million tons of cereal equivalents in 2014 . The number of inhabitants with a food deficit was about 0.85 billion before the 2008 crisis and was decreasing annually, but it increased abruptly after 2008 up to 1 billion inhabitants, and is slowly decreasing now. Assuming a World average water consumption for food of $1300 \mathrm{~m}^{3} / \mathrm{y}$ per capita in $2000,1,400 \mathrm{~m}^{3} / \mathrm{y}$ in 2050 and $1500 \mathrm{~m}^{3} / \mathrm{y}$ in 2100 , a volume of water of around $8200 \mathrm{~km}^{3} / \mathrm{y}$ was needed in $2000,13000 \mathrm{~km}^{3} / \mathrm{y}$ will be needed in 2050 and $16500 \mathrm{~km}^{3} / \mathrm{y}$ in 2100 (Marsily 2009). Can bioenergy be added to food production? Will that much water be available on earth, and where will it come from? Is climate change going to modify the answers to these questions? Can severe droughts occur? Can there be conflicts related to a food deficit? Some preliminary answers and scenarios for food production will be given in this paper from a hydrologist viewpoint.
\end{abstract}

Key words: World water stocks and balance - Climate change - Food supply - Bioenergy - Green and Blue water Virtual water - El Niño - Water conflicts.

\section{Where does the water we use today come from?}

Natural water on earth has two origins: the perennial water cycle, the major one, and the stocks of freshwater. Below is an assessment of the origin and use of water for the year 2000, for which most of the data are available, but one must keep in mind that all these numbers come from different sources, may not always be consistent, and are all uncertain.

\subsection{Freshwater stocks}


The freshwater stocks are very large (see for example. Marsily 2009): about 28.2 million $\mathrm{km}^{3}$ of ice and 15 million $\mathrm{km}^{3}$ of groundwater (which may be brackish in many places), plus about 0.3 million $\mathrm{km}^{3}$ in lakes, and 8,500 $\mathrm{km}^{3}$ in artificial reservoirs (Chao et al. 2008), plus the newly discovered 0.5 million $\mathrm{km}^{3}$ of semi-freshwater stored in aquifers beneath the seabed (Post et al. 2013), whose magnitude and salinity still needs to be confirmed and which may be difficult to exploit. The ice stock is decreasing because of climate change (IPCC 2014), and today the flow in the rivers from high mountains with glaciers is increased because the ice is melting.

In fact, according to Rabatel et al. (2013), the tropical Andes harbour more than $99 \%$ of all tropical glaciers: Peru (71 \%), Bolivia (20\%), Ecuador (4\%) and Colombia-Venezuela (4\%). Most of the glaciers in the Cordillera Blanca, the largest tropical glacier train in the world, are predicted to disappear, especially at lower elevations (Bradley et al. 2006; Vuille 2013) and some as soon as between 2025 and 2045 (Ramirez et al. 2007; Baraer et al. 2012). The predictions of all the different climate scenarios (IPCC 2014) are that they will melt as the warming rate has already accelerated over the last three decades and glacier loss is now occurring at an unprecedented rate (Vuille et al. 2008). In fact, glaciers all along the Andes cordillera, north to south, are reported to be retreating at varying rates and to be threatened by future climate change (Nicholson et al. 2009; Willis et al. 2012; Davies and Glasser 2012; Diaz et al. 2014). However this retreat is particularly critical for Peru and Bolivia, as Peru's highly populated arid Pacific coast depends on water stocks from glacial melt (for drinking, irrigation, and hydroelectric power) to compensate for the lack of rainfall, especially during the May to September dry season, when nearly all of the river-flow is due to glacial melt (Chevallier et al. 2011). In Bolivia, glaciers in the southern Cordillera Real supply approximately $15 \%$ (30\% during the dry season) of the drinking water for the urban areas of La Paz and El Alto (Ramirez et al. 2007; Soruco 2012; Moya Quiroga et al. 2014).

The groundwater stocks are also decreasing, as shown in Table 1, taken form Zimmer (2013) and Wada et al. (2012):

Table 1: Amount of irrigation water taken from the groundwater stocks, for the year 2000 (from Zimmer 2013, and Wada et al. 2012)

\begin{tabular}{|l|l|l|l|}
\hline Country & $\begin{array}{l}\text { Amount } \\
\text { groundwater } \\
\text { pumped annually } \\
\mathbf{k m}^{3} / \mathbf{y}\end{array}$ & $\begin{array}{l}\text { Amount of excess } \\
\text { withdrawal compared to } \\
\text { natural recharge } \\
\mathbf{k m}^{3} / \mathbf{y}\end{array}$ & $\begin{array}{l}\text { Total annual } \\
\text { consumption } \\
\text { irrigation } \\
\mathbf{k m}^{3} / \mathbf{y}\end{array}$ \\
\hline India & 190 & 71 & 600 \\
\hline Unites States & 115 & 32 & 204 \\
\hline China & 97 & 22 & 403 \\
\hline Pakistan & 55 & 37 & 183 \\
\hline Iran & 53 & 27 & 59 \\
\hline Mexico & 38 & 11 & 71 \\
\hline Total & 548 & 200 & 1520 \\
\hline PLANET EARTH & 734 & 256 & 2510 \\
\hline
\end{tabular}

In Table 1, the countries are listed in decreasing order of annual groundwater withdrawals for irrigation. The data are for the year 2000. The second column is the excess withdrawal, i.e. the amount of water taken from stocks. The third column is the total consumption by irrigation, from groundwater and surface water. The numbers in the line "Planet earth" show the sum for all countries where estimates were available, and not just for the first six listed. These numbers are quite uncertain; other authors reach values about half as high as these, see e.g. Konikow (2011), Döll et al. (2014; 2015, this volume). But the comparison of the withdrawals from the stocks with the total amount of irrigation water is of concern: about $10 \%$ of the irrigation water used today is non-sustainable, and comes from 
groundwater stocks that eventually will run out. This is of special concern at least for India and China, where the stocks will last for perhaps another 10 to 30 years. The annual amount taken from stocks is relatively small compared to the global stocks $\left(256 \mathrm{~km}^{3}\right.$ compared to 15 million $\left.\mathrm{km}^{3}\right)$, but this is a false image: what matters is the volume of residual freshwater stocks that can be exploited at the local and not at the global scale: if the stock is large e.g. in the Sahara desert or in Siberia, is it of any use in India or China?

\subsection{The water cycle}

The renewable fresh water resources of Planet Earth, adapted from Shiklomanov $(1999,2003)$ and Trenberth et al. (2007), are estimated today at $113,000 \mathrm{~km}^{3} / \mathrm{y}$, which is the total amount of rainfall and snowfall on the continental surfaces including the Antarctic and Greenland ice sheets (but not the floating ice of the North pole). This corresponds on average to a rain-depth of $840 \mathrm{~mm} \mathrm{y}^{-1}$. The fate of this rainwater is as follows:

$-73000 \mathrm{~km}^{3} / \mathrm{y}(65 \%)$ returns to the atmosphere, by direct evaporation and mostly by plant transpiration. This amount is partly used by rain-fed agriculture and pasture (in 2000, $6300 \mathrm{~km}^{3} / \mathrm{y}$ ) and sustains the needs of all terrestrial ecosystems. It is used to $100 \%$ by nature; hence it is by no means a "loss". It is now called "Green Water" (Hoekstra et al. 2011; Hoekstra and Mekonnen, 2012).

$-4000 \mathrm{~km}^{3} / \mathrm{y}(3 \%)$ represents the melting of icebergs, broken-off from the Antarctic and Greenland ice sheets, which melt in the sea and participate in the general ocean circulation.

$-36000 \mathrm{~km}^{3} / \mathrm{y}(32 \%)$ is the total flow on the continents, which is called "Blue Water"; it consists of:

$-26000 \mathrm{~km}^{3} / \mathrm{y}(23 \%)$ of direct runoff into rivers when it rains; part of which can be used directly, or stored in reservoirs for later use. This water is also used by the aquatic ecosystems, in wet zones, rivers, lakes, and coastal zones.

$-10000 \mathrm{~km}^{3} / \mathrm{y}(9 \%)$ infiltrates into the ground and feed the aquifers, which in turn feed the rivers when it does not rain, $\left(7800 \mathrm{~km}^{3} / \mathrm{y}\right)$, or flow directly into the seas or endorheic zones $\left(2200 \mathrm{~km}^{3} / \mathrm{y}\right)$.

A first step is to define the resource available to humans based on these numbers. In general, the volume of $73000 \mathrm{~km}^{3} / \mathrm{y}$ of evapotranspired water going back to the atmosphere (Green Water) is not considered a resource, which constitutes a major error since, e.g. for the year 2000 , of the estimated $8,200 \mathrm{~km}^{3} / \mathrm{y}$ of water consumed by agriculture to produce our food, about $6300 \mathrm{~km}^{3} / \mathrm{y}$ is Green Water $\left(5500 \mathrm{~km}^{3} / \mathrm{y}\right.$ on rain-fed farm-land, over 1.34 billion ha, and $0.840 \mathrm{~km}^{3} / \mathrm{y}$ on rain-fed pasture, over 3.3 billion ha), and only $1800 \mathrm{~km}^{3} / \mathrm{y}$ is Blue Water, used for irrigation on 0.26 billion ha of irrigated land (Griffon 2006; Académie des Sciences 2006; Marsily 2009). The total surface area of the continents is 13.3 billion ha, of which (according to the FAO, 2002, for 2000) approximately 1.6 is farm-land, 3.7 is forest, 4.6 is grass and shrub, and 3.4 is bare land; the total area that could potentially be farmed, at the expense of forests and grass and shrub, is 4.2 billion ha. Let us assume for a moment that all the arable land on earth was used for rain-fed agriculture. The water evapotranspired by these 4.2 billion ha would amount to approximately $23000 \mathrm{~km}^{3} / \mathrm{y}$ (assuming linearity between area and evapotranpiration), which is still larger than the estimated water needs to feed 11 billion inhabitants in $2100\left(16500 \mathrm{~km}^{3} / \mathrm{y}\right)$.

However, the arable land that is not directly farmed by humans today, about 2.6 billion ha, is of course not bare soils: it contains all the remaining natural ecosystems, from the tropical forests to the northern forests, the grass lands, the bush land, the wetlands, etc. Transforming more land into farmland for agriculture, where this is possible, therefore has an environmental cost, i.e. that of reducing natural ecosystems and biodiversity.

Similarly, when water is withdrawn from a river, e.g. for irrigation purposes, it is also withdrawn from the normal functioning of a natural ecosystem. In these systems, life has become adapted to making use of the resource, as efficiently as possible. The aquatic life is therefore at equilibrium with the natural flow, its seasonal variations, its

\footnotetext{
${ }^{1}$ The "consumed" water is that which is evaporated and returns to the atmosphere; in "irrigation", it represents on average $75 \%$ of the withdrawal; in domestic and industrial use, it represents about $15 \%$ of the withdrawal, the rest is the return flow which goes back to the continental water cycle.
} 
floods and inundation of the plains, its droughts and their frequency, etc. Any withdrawal of water or any artificial regulation (e.g. by a dam) of the natural functioning of the system will inevitably have a negative impact on the natural ecosystems, from the source to the mouth of the river, and even on coastal areas whose ecosystems depend on the flux of freshwater into the sea for their survival. Note however that on average, at the global scale, one ha of irrigated land produces about three times more food than one ha of rain-fed land (Musy and Higy 2010).

Thus the reality is as follows: the global renewable resource of freshwater on Earth (total rainfall on the continents, $113,000 \mathrm{~km}^{3} / \mathrm{y}$ ) is very large, and today less than $10 \%$ of it is used by humans, but the remaining $90 \%$ are entirely used to sustain the natural ecosystems, and the biodiversity that makes the World what it is. Globally, it may be possible to increase the part of the resource used by humans, but only at the expense of the functioning of the natural ecosystems. The question is then: where is the least damage done by withdrawing water from the natural systems?

The water resource is unequally distributed on earth. At high latitudes, in the so-called "cold deserts", precipitation is very low,,$<200 \mathrm{~mm} / \mathrm{y}$. Rainfall increases in the temperate zone, where it reaches 700 to $1000 \mathrm{~mm} / \mathrm{y}$, then decreases (at the latitude of the Mediterranean zone) to practically zero at the latitude of the "hot deserts", such as the Sahara, the Arabic Peninsula, the Taklimakan desert, Mexico, etc. It then increases again in the tropical and equatorial zone, to reach an order of $2300 \mathrm{~mm} / \mathrm{y}$. The same type of climate distribution is found for every meridian and in both hemispheres (Shelton 2009).

In Table 2, from Viviroli et al. 2007), the percentage of the World population is given as a function of the climate and vegetation zones, with the amount of direct river runoff. One can see that the World population is not distributed in accordance with the water resource. This is one reason for the local water shortages. Figure 1 gives the areas of the World where there are water shortages at present (Rijsberman 2006; IWMI 2007; WWAP 2012; WWDR 2012), based on Blue Water only. But two causes are outlined on this map: (i) physical water scarcity, where more than $75 \%$ of the river flow (Blue Water) is withdrawn for human use, and (ii) economical water scarcity, where the Blue Water is available, but not exploited for lack of resources to finance the equipment to do so (dams, canals, irrigation systems...). This zone of "economical scarcity" harbours the 0.8 to 1 billion undernourished inhabitants of the planet, not the "physical scarcity" zone. This is very important to realize, hunger is not, today at least, linked to a lack of water.

Table 2. Climate classification adapted from Leemans (1992) and life zones from Holdridge (1967). In Viviroli et al. ( 2007)

\begin{tabular}{|c|c|c|c|c|c|}
\hline & Contains aggregated Holdridge life zones & $\begin{array}{c}\text { A } \\
(\%)\end{array}$ & $\begin{array}{c}\text { POP } \\
(\%)\end{array}$ & $\begin{array}{c}\text { Q } \\
(\%)\end{array}$ & $\begin{array}{c}\mathrm{q} \\
\left(\mathrm{mm} \mathrm{y}^{-1}\right)\end{array}$ \\
\hline Polar and Cold & Tundra and Polar; Cold Parklands & 14.8 & 3.2 & 11.9 & 245 \\
\hline Cool & Forest Tundra; Boreal Forest & 11.3 & 4.0 & 11.6 & 313 \\
\hline Temperate & Temperate Forest; Warm Temperate Forest & 9.9 & 23.3 & 15.2 & 465 \\
\hline Steppe & Steppe; Chaparral & 9.7 & 13.6 & 1.9 & 59 \\
\hline Arid & Cool Desert; Hot Desert & 18.5 & 7.9 & 0.3 & 5 \\
\hline Sub-tropical & Tropical Semi-Arid; Tropical Dry Forest & 18.3 & 24.8 & 8.8 & 147 \\
\hline $\begin{array}{c}\text { Humid } \\
\text { Tropical }\end{array}$ & $\begin{array}{c}\text { Tropical Seasonal Forest; } \\
\text { Tropical Rain Forest }\end{array}$ & 17.5 & 23.2 & 50.3 & 872 \\
\hline
\end{tabular}

A: Share in continental surface area (total: 133.6 million $\mathrm{km}^{2}$ )

POP: Share in global population (total: 6.2 billion people in 2000)

Q: share in global discharge (total: $36,000 \mathrm{~km}^{3} \mathrm{y}^{-1}$ )

q: Average runoff, $\mathrm{mm} \mathrm{y}^{-1}$; Antarctica and glaciated parts of Greenland are excluded. 


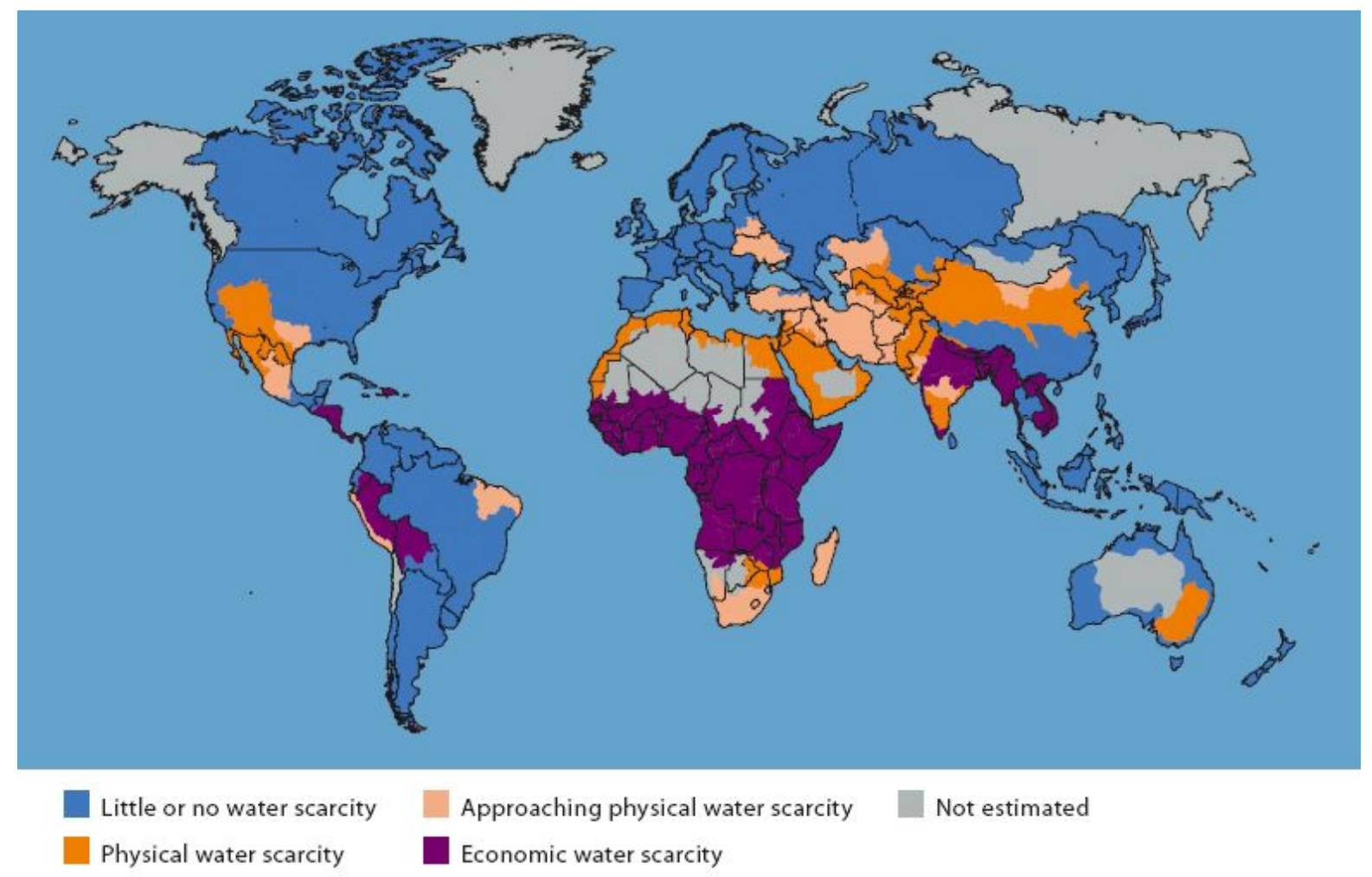

Fig. 1. Physical and Economic Water Scarcity (WWAP 2012).

\subsection{Virtual water, example of Tunisia}

The concept of "Virtual Water" was introduced by Allan (1988). It represents the amount of water needed to produce the goods that are imported or exported from one country to another. In this case, the goods are agricultural products, but it could be any kind of product. To truly understand the role of Virtual Water in the water balance of a country, take one example, Tunisia, a country in the arid zone where the water balance has been thoroughly studied for a long time (Chahed et al. 2008; Besbes et al. 2009, 2014). The presentation below is taken from these authors.

Tunisia is situated in North Africa, and bordered by Algeria, Libya, the Mediterranean Sea, and the Sahara. The country has a surface area of $164,420 \mathrm{~km}^{2}$ and had 10 million inhabitants in 2004, and 10.8 in 2013 , according to the National Institute of Statistics-Tunisia. It has about 5 million ha of agricultural land, $11 \%$ of which can be irrigated. The average rainfall is $220 \mathrm{~mm} / \mathrm{y}$, which translates into a rainfall resource of $36 \mathrm{~km}^{3} / \mathrm{y}$. Total hydraulic resources (Blue Water) are estimated at $5 \mathrm{~km}^{3} / \mathrm{y}$ with the current climate, i.e. $3 \mathrm{~km}^{3} / \mathrm{y}$ of runoff and $2 \mathrm{~km}^{3} / \mathrm{y}$ of groundwater flow. It is considered that $2.1 \mathrm{~km}^{3} / \mathrm{y}$ of surface water can be exploited through dam construction, and $1.8 \mathrm{~km}^{3} / \mathrm{y}$ sustainably supplied by groundwater. The Green Water, which is part of the rainfall resource infiltrated into the soil and available for evaporation and consumption by plants, is $23 \mathrm{~km}^{3} / \mathrm{y}$, of which $13 \mathrm{~km} / \mathrm{y}$ refer to the whole extent of arable land ( 5 million ha), and $10 \mathrm{~km}^{3} / \mathrm{y}$ to forest and rangeland. The remaining part of the rainfall is evaporated on bare soils and by wetlands, or transferred to the Mediterranean.

The water demand for food is estimated from the amount of water needed to produce it (Table 3). It is evident that animal products are very demanding compared to vegetal products. This is due to the fact that animals eat vegetal products (e.g. grain, soya), and to the low efficiency of vegetal-to-animal product transformation. 
Table 3. Water needed for food production. Average values of water used in $\mathrm{m}^{3} / \mathrm{t}$ to produce raw food (consumed fraction, not in dry matter), (Renault and Wallender 2000; Zimmer 2013)

\begin{tabular}{|c|c|c|c|}
\hline Vegetal product & $\begin{array}{c}\text { Water needed } \\
\left(\mathrm{m}^{3} \mathrm{t}^{-1}\right)\end{array}$ & Animal product & $\begin{array}{c}\text { Water needed } \\
\left(\mathrm{m}^{3} \mathrm{t}^{-1}\right)\end{array}$ \\
\hline Vegetable oil & 5000 & Beef & 13000 \\
\hline Rice & $1500-2000$ & Poultry & 4100 \\
\hline Wheat & 1000 & Eggs & 2700 \\
\hline Corn & 700 & Milk & 800 \\
\hline Citrus fruits & 400 & & \\
\hline Vegetables & $200-400$ & & \\
\hline Potatoes & 100 & & \\
\hline
\end{tabular}

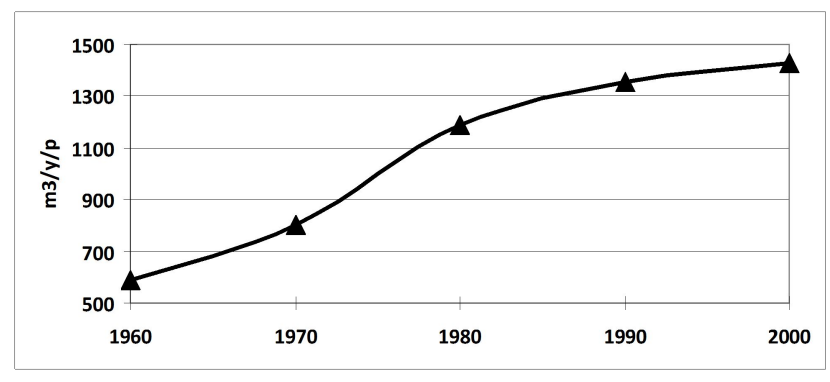

Fig. 2: Evolution of the per capita water equivalent $\left(\mathrm{m}^{3} / \mathrm{y}\right)$ of the Tunisian food demand during the last 40 years.

Based on the average diet in Tunisia, the food water demand in 2004 was about $1450 \mathrm{~m}^{3} / \mathrm{y}$ per capita, while it was only $600 \mathrm{~m}^{3} / \mathrm{y}$ in 1960 , Fig. 2. This strong increase is due to diet changes, in particular an increase of animal product consumption. With 10 million inhabitants in 2004, the water demand for food was $14.5 \mathrm{~km} / \mathrm{y}$, when the available water resource used for agricultural production was $10 \mathrm{~km}^{3} / \mathrm{y}$ (Irrigation, Blue : 2 and Rainfed, Green: 8). Tunisia was therefore in theory short of about $5 \mathrm{~km}^{3} / \mathrm{y}$ of water to meet its food demand, and was obliged to import food (mostly cereals) as "Virtual Water" to balance its water budget. Table 4 gives the actual mean water consumption per type of activity for the years 1990, based on production and trade statistics of food products.

Table 4: Comprehensive water consumption of Tunisia (average values for the years 2000) from Besbes et al. (2009)

\begin{tabular}{|c|c|}
\hline Sector & Water consumption, $\mathbf{~ k m}^{\mathbf{3}} \mathbf{y}$ \\
\hline Irrigation & 2.1 \\
\hline Rain-fed agriculture & 6 \\
\hline Net imported Virtual Water & 3.7 \\
\hline Urban water & 0.4 \\
\hline Industrial water & 0.1 \\
\hline Forests and Rangelands & 5.5 \\
\hline Water storage in dams for future droughts & 0.6 \\
\hline Environment (conservation of wet zones) & 0.1 \\
\hline Total Water Consumption & $\mathbf{1 8 . 5}$ \\
\hline
\end{tabular}


The direct water needs, which include municipalities, industry, and tourism, are small (3\%) compared to the agricultural demand. In average rainfall years, half of the water required to meet Tunisian food requirements is provided by rain-fed agriculture (Green water), one-sixth by irrigated agriculture (Blue water), and almost one-third by Virtual Water in the form of imported food. Tunisia imports the water equivalent of $5.2 \mathrm{~km}^{3} / \mathrm{y}$, essentially in the form of cereals, and exports agricultural products such as citrus fruit, dates, olive oil, and early-season vegetables, equivalent to $1.5 \mathrm{~km}^{3} / \mathrm{y}$ for an average annual net deficit of $3.7 \mathrm{~km}^{3} / \mathrm{y}$ (Chahed et al. 2008). In 2025, with about 12 million inhabitants, and probably less water available because of climate change, Virtual Water is likely to increase to $50 \%$ of the food demand.

Tunisia's food security goals are to satisfy, as far as possible, its basic food needs (cereals, oil, meat, milk). However, it cannot be self-sufficient in some of these products. Most importantly, climate variations cause large fluctuations in the yield from rain-fed agriculture (Besbes et al. 2009). The food trade balance of Tunisia has been negative during the last three decades, except for the rainy years of 1991, 1999, and 2004. This balance depends strongly on cereal imports, which represent close to $45 \%$ of the total value of food commodity imports.

Large-scale hydraulic programmes to increase the Blue Water availability make the water cycle highly artificial, which leads to a reduction of the water feeding natural hydrologic systems, with consequences for the behaviour of continental and coastal aquatic ecosystems; a reduction of recharge to aquifers from wadis (the Arabic term for an ephemeral stream or a dry riverbed where water flows only during the rainy season) situated downstream of large dams; and a progressive salinization of soils irrigated with highly saline water. In these conditions, the protection of the environment and of the resources requires a continuous assessment of the environmental water demand, which should be included in the planning of water allowances: artificial floods for wetlands and groundwater recharge or additional irrigation share to prevent salinization of irrigated soils. Increased irrigation shares for salt leaching in soils were allocated early on, whereas the understanding of other environmental needs requiring a direct water allowance from exploited resources has been progressive and is now an essential component of water-resource planning and management. On a national level, the environmental water demand remains small compared to urban and agricultural requirements, but it represents a growing concern in the planning of future hydraulic programs.

Sometime in the 1980s, by its demographic growth and food diet changes, Tunisia has reached a situation where it was no longer self-sufficient in the balance of its food budget (or its water budget), and needed to import food (cereals) or "Virtual Water". To balance its financial budget, Tunisia needs to export products or services to raise the money needed for food import: phosphates minerals (Tunisia has no significant hydrocarbon nor coal resources), textiles, tourism, services, etc. Provided that food (cereals) is available on the international market, the real problem of Tunisia, given its demographic situation, is not water, it is how to raise the money needed to buy food in the market. In this context, the best use of the available Blue Water may not be agriculture, but other industrial or service activities, with better water efficiency (in terms of $\$ / \mathrm{m}^{3}$ ) and better job efficiency (in terms of jobs $/ \mathrm{m}^{3}$ ) than that offered by agriculture.

But is food available on the World market and likely to remain so in the future?

\section{Scenarios for food production in 2050}

Table 5 (part 1, situation in 2000) is an estimate for 2000 of how much food the Planet produced, with a zonation taken from the Millennium Ecosystem Assessment Report (2005). Listed per zone are: its area, the area suitable for agriculture, the water resources (rain, Green and Blue Water, potentially exploitable Blue Water), the cultivated area in 2000, the percentage of cultivated arable land, the population, the food-need, in million tons of cereal-equivalent (i.e. each type of food is converted into cereals), the average yield in $t / h a$, the amount of water consumed (Blue Water, Green Water, and \% of rainfall), the food deficit or excess, and finally, the amount of arable 
land that is not cultivated and kept as "natural areas", i.e. forest or grassland. Note that these numbers come from different sources, are often not consistent (and therefore adjusted so as to be consistent in Table 5) and highly uncertain; they provide only orders of magnitude.

The water consumed by agriculture in 2000 was $8140 \mathrm{~km}^{3} / \mathrm{y}: 1.34$ billion ha of rain-fed agriculture, consuming $5500 \mathrm{~km}^{3} / \mathrm{y}$ of water; 3.3 billion ha of rain-fed pasture consuming $840 \mathrm{~km} / \mathrm{y}$; and 234 million ha of irrigated agriculture, consuming $1830 \mathrm{~km}^{3} / \mathrm{y}$ of water. It represents $97 \%$ of the total water consumption by man. Three major cereals, rice, wheat and maize, each representing approximately one third, constitute $60 \%$ of the food consumption. The total food production is about 3.3 billion tons of cereal-equivalents per year, for 6.2 billion people. However, about 1 billion are under-nourished; the amount of the food deficit is about 40 million tons per year, mostly in Asia and Sub-Saharan Africa, as shown in Fig. 1. The current rate of food production increase does not correspond to that of the demographic growth, or at least, does not reduce the food deficit fast enough. The food yield is on average $2.11 \mathrm{t} / \mathrm{ha}$, but varies greatly from 0.75 (Russia and the Commonwealth of Independent States, CIS), 0.92 (Sub-Saharan Africa, SS-Africa) to about 2.9 (Asia and the countries of the Organisation for Economic Co-operation and Development, OECD). The water efficiency ( $\mathrm{m}^{3}$ of water used to produce $1 \mathrm{t}$ of cereals) is on average $2460 \mathrm{~m}^{3} / \mathrm{t}$, with SS-Africa at $6150 \mathrm{~m}^{3} / \mathrm{t}$, Russia+CIS at $4600 \mathrm{~m}^{3} / \mathrm{t}$ and OECD at $1040 \mathrm{~m}^{3} / \mathrm{t}$.

The first observation is that the major problems are expected to occur in Asia and in the West Asia-North Africa (WANA) countries, where the ratio of consumed water (Blue + Green) to rainfall is about $16 \%$ (World average: $8 \%$ ) and, most importantly, the ratio of farm land to arable land is $75 \%$ and $87 \%$, respectively (World average: $37 \%$ ). The major issue concerning food, as we will see, is the availability of arable land, not water. The consumed water is on World average 78\% Green Water and 22\% Blue Water, but again Asia and WANA have quite different ratios: $70 \%$ Green, $30 \%$ Blue, and 53\% Green, $47 \%$ Blue, respectively. A final observation is that "natural" (protected) land, i.e. arable land that is not cultivated and is covered by forests and grassland, is mostly found in Latin America (33\% of the total), Sub-Saharan Africa (31\%) and OECD countries (19\%).

To predict the food balance for the years 2050 or 2100 , one needs to determine:

-the number of inhabitants on earth, -their eating habits and the amount of wasted food, -the efficiency of food production per $\mathrm{m}^{3}$ of water, i.e. the efficiency of the agricultural water use, -the effects of climate change, -the amount of cultivated land.

To answer the first question, recent demographic projections made by the UN (2012, see Gerland et al. 2014 and Fig. 3) converge towards 9.5 billion inhabitants (from 9.1 to 9.9) in 2050, and towards 11 billion in 2100 (from 9.5 to 12.5), but the demographic growth will continue after 2100, mainly in Africa. 

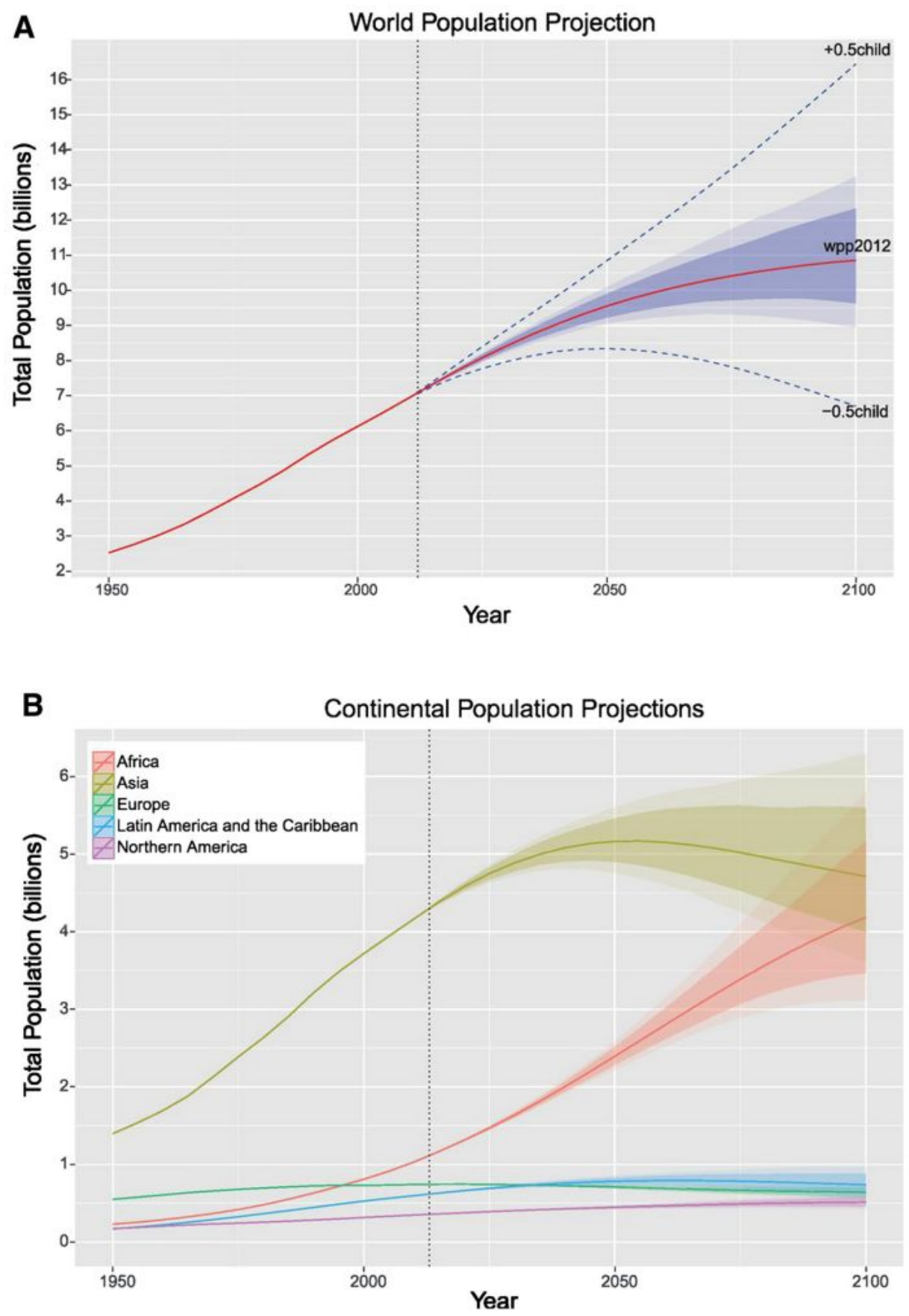

Fig. 3 : Demographic growth as projected by the UN in 2012, from Gerland et al. (2014). "World and continental population projections. A UN 2012 world population projection (solid red line), with $80 \%$ prediction interval (dark shaded area), 95\% prediction interval (light shaded area), and the traditional UN high and low variants (dashed blue lines). B UN 2012 population projections by continent. In both panels, the vertical dashed line denotes 2012. 
The second question (eating habits) is more difficult. Table 3 shows the amount of water needed to produce the different types of food consumed today, and Table 5 the water actually used per geographic zone and the yield. If a country goes from a mostly vegetarian diet to a meat-rich one, the amount of water required for food production will greatly increase, as e.g. one $\mathrm{kg}$ of beef requires 13 times more water than one $\mathrm{kg}$ of wheat... At this moment, Asia is more vegetarian than meat-consuming, but this is changing rapidly, in particular in China and India. Assumptions have thus to be made on the food habit evolution.

The third question concerning agricultural efficiency (see Table 5) is also difficult to answer, particularly for such a long forecasting period, i.e. 35 to 85 years. But it is generally assumed that water use efficiency could be increased by $20 \%$ by 2050 , i.e. that the same amount of food could be produced with $20 \%$ less water. In short, "more crop per drop" is feasible. When the yield is good (e.g. above to $2-3 \mathrm{t} / \mathrm{ha}$ ), the water consumption per ton is about that of Table 3; but when the yield is low (e.g. about $1 \mathrm{t} / \mathrm{ha}$ ), the water consumption per ton becomes much higher (up to eight times more), because the plants are less developed, they do not cover the soil, and much water is evaporated, not transpired (Zimmer 2013; Rockström 2004). Increasing the yield (e.g. by better plant selection, use of fertilizers, protection against pests,...) will also increase water efficiency.

The effects of climate change are discussed in Section 3.

Griffon (2006), Agrimonde (2010), and FAO (2015a), among many others, have built scenarios of food needs and food production increase for 2050. One of these scenarios is presented in Table 5, part 2, the situation for 2050 . Compared to 2000, the increase in food production achieved by 2050 should be from 3300 million t/y to 6180 million $\mathrm{t} / \mathrm{y}$. This number takes into account population growth, the age of the population, the eradication of hunger, and diet changes as a linear continuation of what has been observed in the past 10 years. This food production increase can be obtained by:

-increasing yields and crop efficiency,

-increasing the amount of irrigated land,

-increasing the amount of cultivated rain-fed land.

-reducing food losses, which are currently estimated at 30\% of food production (SIWI, 2008).

At present, the rate of areal increase in irrigated land is low, less than 2 million ha/year. In the years 2000s, the World Bank and other funding agencies stopped financing large irrigation projects, as their technical and financial success was considered poor, but they are now revising their opinions. Unless its rate of increase is raised very rapidly, by at least a factor of ten, irrigation is not going to be the main factor of production growth. Scenario 1 in Table 5 is based on small technology changes, nominal investment in irrigation, major increase in rain-fed agriculture in Africa (to satisfy the demand on this continent), in South America, Russia-CIS and OECD countries, to compensate for the deficits in Asia and WANA, unable to be self-sufficient. Many tests have been performed, but the major conclusion is indeed that Asia and WANA countries cannot be self-sufficient food producers in 2050, as is already the case of WANA today. The limiting factor is soils for Asia, and water for WANA. SS-Africa is currently in food deficit, and must import food, but there is plenty of arable land and water in SS-Africa, and it could be selfsufficient, as is assumed in Table 5, but this is a very strong assumption and requires rapid development of the agricultural production in SS-Africa, which may or may not occur. The deficits from Asia and WANA are assumed to be met by extra production by Latin America, OECD countries and Russia-CIS. But other scenarios could equally well have been built, with SS-Africa becoming an exporter, or with different ratios between the three exporting zones.

The net result of this scenario is that an increase of about 1 billion ha of rain-fed cultivated land would be required, thus reducing the "protected area" (non-cultivated arable land) by the same amount. This number is probably too large; other scenarios produce half or even a third of that number, with different assumptions on yield and food habits. If this scenario is linearly extrapolated to 2100 , with 11 billion inhabitants, a total production of 
7,200 million tons/y of cereal-equivalents would be required, i.e. an additional increase of rain-fed cultivated land of about 0.4 billion ha, and a residual "protected area" of 1.2 billion ha, instead of 2.6 today.

Scenario 2 in Table 5 is again taken from Griffon (2006). It assumes that in 2050, in addition to food production, land is also used to produce second-generation biofuels. In this scenario, 585 million ha are taken out of the pool of arable land to produce energy, at an average yield of 3.3 tons of oil equivalent (toe) per ha, producing 1.9 billion toe/year. According to A. Müller in FAO (2006), up to $25 \%$ or the World energy needs could come from biofuels within 25 years. But these 1855 million toe would only represent $8 \%$ of the energy needs of the planet in 2050 , not $25 \%$, and would reduce the "protected area" to 1 billion ha in 2050 .

Water desalination, often mentioned as the solution, is not a realistic option for food production, given its cost and energy requirements (from 2.5 to $6 \mathrm{kWh} / \mathrm{m}^{3}$ for seawater with reverse osmosis). Just to provide an order of magnitude, if $4000 \mathrm{~km}^{3} / \mathrm{y}$ of water (to produce, by irrigation , the additional food needed from 2000 to 2050) were to be produced from seawater desalination by reverse osmosis, it would require an amount of energy equal to half of that produced today per year from the current exploitation of hydrocarbons. Artificially growing food plants without soil can be efficient, but is also extremely costly, and will most likely not be the solution. Increasing the food productivity by genetically selected or modified plants is certainly a fascinating research area, but, according to Tardieu (2005), it is today very difficult to expect significant reduction in plant water consumption, as there is a trade-off between the evapotranspiration of water through the stomata of the leaves, and the entrance of $\mathrm{CO}_{2}$ for photosynthesis: reducing one also reduces the second. But plants more tolerant to droughts can probably be developed.

Raising insects to provide animal proteins as feed for farm animals, fishes, or as human food is quite often mentioned (see Rumpold and Schlueter 2013; Makkar et al. 2014, and FAO 2015b). Today, about two billion inhabitants of the planet eat insects, but they are mostly gathered, not farmed. The significance of this protein input in the food balance is unknown, but assumed to be currently very small. Encouraged by FAO, insect farming is developing rapidly; the bugs can be cooked and eaten, or lyophilized and used as a protein extract which is then incorporated in food or feed. The energy content of insects varies greatly (FAO, 2012), in general from 90 to 200 $\mathrm{kcal}$ per $100 \mathrm{~g}$ of raw food, with extreme values for Australian ants $(1272 \mathrm{kcal} / 100 \mathrm{~g})$, Ivory Coast termites $(535$ $\mathrm{kcal} / 100 \mathrm{~g}$ ) or Mexican ants (404 kcal/100g); for comparison, raw meat is on the order of 113 to $208 \mathrm{kcal} / 100 \mathrm{~g}$. Is this the solution to the food problem? It may help, but it cannot be considered as a real breakthrough. Indeed, when insects are farmed, they must be fed with vegetal products or with animal or vegetal waste. But then they become competitors to other "transformers" of vegetal or waste into animal products: with $10 \mathrm{~kg}$ of vegetal matter, one can make $1 \mathrm{~kg}$ of beef, $3 \mathrm{~kg}$ of pork, $5 \mathrm{~kg}$ of chicken, and $7 \mathrm{~kg}$ of insects. By using insects, one only increases productivity by a factor of 1.4, at least with the current species. Many studies are furthermore required to evaluate the long-term health effects of such food.

Table 5. Estimates for the years 2000 and 2050 of the planet food production, based on the cultivated area of agricultural land, yields, global amount of water consumed (not withdrawn) by humans from the water cycle (Blue and Green Water), and food needs (adapted from Griffon 2006; Marsily 2007, 2009; Agrimonde 2010; Académie des Science, 2011; Zimmer 2013). All these numbers are highly uncertain and sometimes based on the assumption of a linear proportion with the population. They are only orders of magnitudes, not precise estimates. 


\begin{tabular}{|c|c|c|c|c|c|c|c|}
\hline Area & Asia & $\begin{array}{l}\text { Latin } \\
\text { America }\end{array}$ & $\begin{array}{l}\text { West } \\
\text { Asia and } \\
\text { North } \\
\text { Africa }\end{array}$ & $\begin{array}{l}\text { Sub- } \\
\text { Saharan } \\
\text { Africa }\end{array}$ & OECD & $\begin{array}{l}\text { Russia } \\
+ \text { CIS }\end{array}$ & World \\
\hline Area, million ha & 2090 & 2070 & 1180 & 2430 & 3380 & 2190 & 13340 \\
\hline \multicolumn{8}{|c|}{ Situation in 2000} \\
\hline $\begin{array}{l}\text { Area suitable for agriculture, } \\
\text { million ha }\end{array}$ & 585 & 1066 & 99 & 1031 & 874 & 497 & 4152 \\
\hline $\begin{array}{l}\text { Water resources, thousands of } \\
\mathrm{km}^{3} / \text { year } \\
\text { Rainfall } \\
\text { Green Water } \\
\text { Blue Water }\end{array}$ & $\begin{array}{c}21.6 \\
11.9 \\
9.8\end{array}$ & $\begin{array}{c}30.6 \\
8.3 \\
13.2\end{array}$ & $\begin{array}{l}1.8 \\
1.5 \\
0.25\end{array}$ & $\begin{array}{c}19.9 \\
15.5 \\
4.4\end{array}$ & $\begin{array}{c}22.4 \\
14.3 \\
8.1\end{array}$ & $\begin{array}{c}9.2 \\
2.5 \\
4\end{array}$ & $\begin{array}{c}105.5 \\
54 \\
39.7\end{array}$ \\
\hline $\begin{array}{c}\text { Exploitable Blue Water and ratio to } \\
\text { Total Blue Water }\end{array}$ & $\begin{array}{c}9.3 \\
95 \%\end{array}$ & $\begin{array}{c}8.7 \\
66 \%\end{array}$ & $\begin{array}{l}0.24 \\
96 \%\end{array}$ & $\begin{array}{c}4.1 \\
93 \%\end{array}$ & $\begin{array}{c}5.6 \\
69 \%\end{array}$ & $\begin{array}{c}1.8 \\
45 \%\end{array}$ & $\begin{array}{l}29.7 \\
75 \%\end{array}$ \\
\hline Cultivated area, million ha (2000) & 439 & 203 & 86 & 228 & 377 & 255 & 1,564 \\
\hline$\%$ cultivated & $75 \%$ & $19 \%$ & $87 \%$ & $22 \%$ & $43 \%$ & $51 \%$ & $37 \%$ \\
\hline Population, million & 3322 & 538 & 372 & 706 & 987 & 279 & 6200 \\
\hline Food need, million tons/year & 1310 & 350 & 220 & 250 & 1020 & 190 & 3340 \\
\hline Food production, million tons/year & 1270 & 425 & 145 & 200 & 1,070 & 190 & 3300 \\
\hline $\begin{array}{l}\text { Average yield, } \mathrm{t} / \mathrm{ha} \\
\text { and } \mathrm{m}^{3} / \mathrm{t}\end{array}$ & $\begin{array}{l}2.96 \\
2830\end{array}$ & $\begin{array}{l}2.12 \\
2420\end{array}$ & $\begin{array}{l}1.71 \\
1860\end{array}$ & $\begin{array}{l}0.92 \\
6150\end{array}$ & $\begin{array}{l}2.84 \\
1040\end{array}$ & $\begin{array}{l}0.75 \\
4600\end{array}$ & $\begin{array}{l}2.11 \\
2480\end{array}$ \\
\hline $\begin{array}{c}\text { Water consumed, } \\
\text { thousands } \mathrm{km}^{3} / \mathrm{y} \\
\text { blue }+ \text { green } \\
\% \text { of rainfall }\end{array}$ & $\begin{array}{c}3.6 \\
16 \%\end{array}$ & $\begin{array}{l}1.03 \\
3.3 \%\end{array}$ & $\begin{array}{l}0.27 \\
15 \%\end{array}$ & $\begin{array}{c}1.23 \\
6 \%\end{array}$ & $\begin{array}{c}\sim 1.12 \\
5 \%\end{array}$ & $\begin{array}{l}0.89 \\
10 \%\end{array}$ & $\begin{array}{l}8.14 \\
8 \%\end{array}$ \\
\hline $\begin{array}{c}\% \text { Blue Water for irrigation } \\
\% \text { Green Water }\end{array}$ & $\begin{array}{l}\sim 30 \% \\
\sim 70 \%\end{array}$ & $\begin{array}{l}11 \% \\
89 \%\end{array}$ & $\begin{array}{l}53 \% \\
47 \%\end{array}$ & $\begin{array}{c}3 \% \\
97 \%\end{array}$ & $\begin{array}{l}\sim 17 \% \\
\sim 83 \%\end{array}$ & $\begin{array}{l}21 \% \\
79 \%\end{array}$ & $\begin{array}{l}22 \% \\
78 \%\end{array}$ \\
\hline $\begin{array}{l}\text { Food Deficit/Excess } \\
\text { million tons/year }\end{array}$ & -40 & +75 & -75 & -50 & 50 & 0 & -40 \\
\hline \multirow[t]{2}{*}{ Protected areas, million ha } & 156 & 866 & 14 & 813 & 497 & 242 & 2588 \\
\hline & \multicolumn{7}{|c|}{ Situation expected in 2050} \\
\hline $\begin{array}{l}\text { Variation of area suitable for agriculture due } \\
\text { to climate change, million ha } \\
\text { Resulting area available for agriculture }\end{array}$ & $\begin{array}{l}-40 \\
545\end{array}$ & $\begin{array}{c}-40 \\
1026\end{array}$ & $\begin{array}{c}-10 \\
89\end{array}$ & $\begin{array}{c}-20 \\
1011\end{array}$ & $\begin{array}{l}+80 \\
954\end{array}$ & $\begin{array}{l}+80 \\
577\end{array}$ & $\begin{array}{l}+50 \\
4202\end{array}$ \\
\hline \multirow[t]{2}{*}{ Food need, million tons/y } & 2720 & 665 & 455 & 800 & 1300 & 240 & 6180 \\
\hline & \multicolumn{7}{|c|}{ Production scenario 1,2050} \\
\hline $\begin{array}{l}\text { Variation of cultivated area, million ha } \\
\text { Resulting cultivated area }\end{array}$ & $\begin{array}{l}+51 \\
480\end{array}$ & $\begin{array}{c}+346 \\
546\end{array}$ & $\begin{array}{l}+4 \\
89\end{array}$ & $\begin{array}{c}+500 \\
718\end{array}$ & $\begin{array}{l}+80 \\
457\end{array}$ & $\begin{array}{l}+80 \\
335\end{array}$ & $\begin{array}{c}+1061 \\
2625\end{array}$ \\
\hline $\begin{array}{l}\text { Expected yield, } \mathrm{t} / \mathrm{ha} \\
\text { and variation }\end{array}$ & $\begin{array}{r}4,29 \\
+45 \%\end{array}$ & $\begin{array}{r}2,33 \\
+10 \%\end{array}$ & $\begin{array}{c}1,88 \\
+10 \%\end{array}$ & $\begin{array}{c}1,11 \\
+21 \%\end{array}$ & $\begin{array}{r}3,38 \\
+20 \%\end{array}$ & $\begin{array}{c}1 \\
+33 \%\end{array}$ & $\begin{array}{r}2,35 \\
+12 \%\end{array}$ \\
\hline Food production, million $\mathrm{t} /$ year & 2060 & 1270 & 170 & 800 & 1545 & 335 & 6180 \\
\hline Food Deficit/Excess, million tons/year & -660 & +605 & -285 & 0 & +245 & +95 & 0 \\
\hline \multirow[t]{2}{*}{ Protected areas, million ha } & 65 & 480 & 0 & 293 & 497 & 242 & 1577 \\
\hline & \multicolumn{7}{|c|}{ Production scenario 2, bio-energy, 2050} \\
\hline $\begin{array}{l}\text { Cultivated area for bio-energy, } \\
\text { million ha }\end{array}$ & 25 & 220 & 0 & 120 & 150 & 70 & 585 \\
\hline $\begin{array}{c}\text { Expected yield, tons of oil } \\
\text { equivalent (toe)/ha }\end{array}$ & 4 & 4 & 0 & 3 & 2,5 & 2 & 3,2 \\
\hline Energy production, million toe/year & 100 & 880 & 0 & 360 & 375 & 140 & 1855 \\
\hline Protected areas, million ha & 40 & 260 & 0 & 173 & 347 & 172 & 992 \\
\hline
\end{tabular}


Thus, the major conclusion of this survey is that additional food will most likely be produced by an increase of rainfed agriculture, in those areas where land is still available: mostly South America and Africa, and to a lesser extent, Russia + CIS and OECD countries, while other regions such as Asia and WANA will not be able to be self-sufficient in food production. In conclusion, water is not likely to be the limiting factor in controlling the current demographic growth of the planet; there will be enough land and water to produce the required food in normal years, but with:

- Enormous "Virtual Water" trade between continents, as Asia and North Africa will not be self-sufficient and must import food, essentially from South America; see for instance Dalin et al. (2012) who have estimated the current Virtual Water trade at $259 \mathrm{~km}^{3} / \mathrm{y}$ in 1986 and at $567 \mathrm{~km}^{3} / \mathrm{y}$ in 2007.

- Dramatic reduction of the biodiversity and of natural ecosystems all over the World, by a reduction of the "protected areas" on arable land, such as forests and grassland or bush land.

\section{Climate change}

The above picture of the World in 2050 is already grim, but let us now look briefly at the prospects for the effects of climate change. The latest IPCC report (2014) shows that the effects of climate changes are fairly well predicted as far as the temperature is concerned, for any specified emission scenario, but that their hydrologic effects are still poorly predicted. Nevertheless, the current prediction is for a global increase in the total rainfall, the hydrologic cycle being accelerated, with a displacement towards the poles of the climate zones, which have been described above. In the Northern hemisphere, it will rain more e.g. in Northern Europe, less in Southern Europe and North Africa, as the Mediterranean climate zone will move North, and more in the tropical zone and in southern Sahara. The summer season in Southern Europe will be drier and the evaporation higher, requiring greater irrigationwater supplies. The mountain glaciers will melt partly or totally (e.g. in the tropical Andes). The effects of temperature and $\mathrm{CO}_{2}$ concentration changes on crop yields have been summarized by e.g. Agrimonde (2010) or Académie des Sciences (2011) but are not considered here in view of an expected impact ( \pm 5 to $20 \%$ ) much weaker than the uncertainties.

The major issue in the present discussion is whether climate changes will also affect the climate variability, i.e. the frequency or intensity of extreme events, droughts or floods. This is still a controversial issue. The model results apparently do not show significant changes in the extreme-event frequency, unless a four time's higher $\mathrm{CO}_{2}$ concentration in the atmosphere is reached, which hopefully will never occur. At the very minimum, climatologists agree that if the mean of the rainfall distribution is shifted, the whole distribution curve will also be shifted, in the same direction. In other words, if the mean rainfall increases in one area, then the frequency of floods will increase, and that of droughts will decrease (or, at the same frequencies, the magnitude of the floods will increase and that of the droughts will decrease), and vice versa if the mean rainfall decreases.

Whether the shape of the distribution of events will also be modified and not just shifted is debatable. When observations are considered, a record of about 40 years where a change in climate can be detected on the mean is very short for detecting changes in the frequencies of extreme events; but the latest IPCC report (2014) indicates that the variability of climate seems likely to increase. This would mean higher frequencies of extreme events, floods or droughts.

In Table 5, it is assumed that because of climate change, 110 million ha of arable land will be lost in the zones of Mediterranean latitudes, and 160 million ha will be gained in the Northern latitudes because of the warming; moreover 10 million ha would be lost because of sea-level rise, according to IPCC (2014).

\section{Risk of droughts}


Disregarding climate changes, the Earth has always experienced great climate variability, depicted e.g. as the seven years of fat cows and lean cows in the Bible... Some archaeological studies conducted simultaneously in Greece and China seem to show that a severe drought occurred in these two countries around the year $400 \mathrm{AD}$ (Cook 2013; Manning 2013) while other researchers suggest that a major climate-change induced drought may have driven the collapse of the once-flourishing Eastern Mediterranean civilizations towards the end of the 13th century BC, i.e. the late Bronze Age crisis (Kaniewski et al. 2013). It is likely that such events will occur again, the question is: will they severely affect food production, and occur simultaneously on different continents? In 1998, following a strong El Niño event, there was a large deficit in grain production in China and Indonesia at the same time (Rojas et al. 2014; Lizumi et al. 2014). These two countries were able to import and distribute from the World stocks the required amount of grain, and no major adverse consequences were felt; the global food stock of cereals, of the order of 400600 million tons, which is about 2-3 months of the current global consumption, fell to a very low point, but was sufficient. This stock has been decreasing regularly in the last twenty years, and, as a result, the cereal prices have greatly increased since 2006 with a peak in 2010 (the FAO food price index had doubled compared to 1990-2005). But since 2008, good harvests have brought down prices (in 2015, they are only about 30\% higher than for 19902005), and the cereal stocks are back to 630 million tons (March $\left.5^{\text {th }}, 2015\right)$ representing about three months of the World cereal consumption (FAO 2015a).

The current theory is that drought situations will occur in the future (Sheffield and Wood 2011), as they did before, even during the last six decades (Sheffield et al. 2012); droughts are even expected to increase in frequency and severity in the future as a result of climate change, mainly as a consequence of decreasing regional precipitation in some areas but also of increasing evapotranspiration driven by global warming (Dai 2013; Trenberth et al. 2014). However, it is assumed that these droughts will not occur at the same time on all continents, and that a situation of drought here will be compensated by normal or good harvest elsewhere; therefore, no major food shortage would occur (FAO 2003, 2006).

This may be true most of the time. But a brief look at history may be of interest here. It is well known for instance that the major volcanic eruption on Krakatoa in 1883 had a worldwide effect on temperature and rainfall (a global 5\% reduction of rainfall is often mentioned). In 2001, Davis published a historical analysis of the $19^{\text {th }}$ century famines and reported on two severe drought episodes that occurred in 1876-1878 and 1896-1900, simultaneously affecting at least Brazil, China, India and Ethiopia. Contrary to the general belief, in this case very serious droughts occurred at the same time in different places, on different continents; Davis (2001) relates these droughts to very strong El Niño events affecting the monsoon zones.

The consequences of the famines in the $19^{\text {th }}$ century were very severe; Davis (2001) mentions, for each case, around 30 million deaths in China and India only, i.e. a total of $4 \%$ of the World population at that time (around 1.5 billion in 1875). The Nobel Prize laureate in economy Armatyra Sen (Sen and Drèze 1999) analysed the same events, and determined that in most cases of drought, which he called "Food Availability Decline", the main cause of death and famines is not the lack of food, but rather the lack of economic resources of the poor farmers whose crops (their unique source of revenue) have been lost, and who therefore can no longer afford to buy food at the inflated prices. He showed for instance that the same happened in Ethiopia in 1975, when a drought and agricultural disaster in one part of the country created a large famine and many deaths, while in other parts of the same country, food was available, and even the means of transporting it to the famine zone, which was situated along a major highway, but nothing was done.

In this context, it is interesting to look at observed frequencies of very strong El Niño events. Ortlieb (2000) tried to reconstruct, from historical archives in South America, the years of strong and very strong El Niño events from 1525 to 1950. In his list, 1876, 1878 and 1899 were indeed very strong El Niño years, as stated by Davis (2001), but, on average, such very strong El Niño events seem to occur about twice every century: they are indeed relatively rare. 
In conclusion, what this brief survey shows is that once or twice per century, or perhaps more often if climate changes affect the El Niño variability (Cai et al. 2014), a major drought period lasting several years may affect simultaneously several continents, influencing the food production on a global scale (Vicente-Serrano et al. 2011). Stocks will probably not be sufficient to satisfy the demand, as the current level of stocks, which equals about twothree months of global consumption, would rapidly be used up, and its transportation to remote places would still be a problem. The international market prices of food would suddenly become very high, and "Food Availability Decline" would become a reality, generating famines of unknown magnitude. The poor countries or the poor rural communities affected by the droughts would be the first to suffer, but may not be the only ones.

There is no reason to assume that this cannot occur. What is however unknown is when: Next year? Ten years from now? The only means of preventing such a catastrophe would be to very significantly increase the World food stocks, or water stocks. But where to put the food stocks? Near harbours for easy access and transportation? Who would pay?

\section{Conflicts}

Since at least the Neolithic Revolution, people have identified water as a commodity and source of economic power and have manipulated its flow (Mithen 2012). It is also well-known that throughout the World history, political and environmental mismanagement, associated with climatic causes, has had a catalytic effect on large-scale disasters, including the decline/demise of complex societies, such as for example the ancient Maya civilization (Demarest 2004). This Mayan decline is related to complex and intricate political and environmental reasons (Hodell et al. 1995; Turner and Sabloff 2012; Masson 2012), where successive dry periods were indeed the culprits (Kennett et al. 2012; Denommee et al. 2014). More recently, the Sudanese 60-year long war, which started in 1955, has also been linked to two long-lasting droughts (1967-1973 and 1980-2000), that have caused widespread population displacement during which thousands died of starvation (Welzer 2012). Similarly, in the ongoing Syrian crisis, water mismanagement and climatic conditions (Gleick 2014; Kelley et al. 2015) have played a role in the deterioration of Syria's economic conditions, magnifying religious and sociopolitical, even geopolitical, factors (Azmeh 2014).

Of course water conflicts are not only related to water scarcity. They may arise due to flooding, water-quality degradation, but, according to Wolf (1995), for the most part, they are indeed related to water deficits. As shown above, demographic growth is likely to generate water stresses, or rather, food deficits. Let us cite here two dramatic examples, Easter Island and Rwanda, as described by Diamond (2005).

(i) Easter Island was discovered in 1722 (at Easter) by the Dutch navigator Jakob Roggeveen. He found a civilization that was totally isolated, devastated, and whose members thought that they were alone on earth, in the middle of a big ocean. From the $15^{\text {th }}$ to the 17 th century, the inhabitants had destroyed their environment by cutting down all the trees on the island, only to use them as rollers to move the huge stone statues, the Moaï, which served as emblems of power and nobility to the priests and leaders. The soil erosion and loss of fertility that resulted made it impossible to feed a population estimated to have been in the range of 3000 to 30000 individuals. In 1680, approximately, an uprising against the priests and leaders occurred, with massacres and cannibalism, reducing the population to about $30 \%$ of its initial numbers. Food deficit can indeed generate large conflicts...

(ii) The second example, Rwanda, is more controversial. In 1994, genocide occurred in Rwanda (see http://en.wikipedia.org/wiki/Rwandan_Genocide), where 500,000 to 800,000 people (about 11 to $20 \%$ of the population) were killed with machetes over a period of 100 days (from April 6th, 1994 to July 16th, 1994). The usual explanation is that two local tribes, the Hutus and the Tutsis, went to war for political reasons, the Hutus (usually laborers), $85 \%$ of the population, having been kept as "second-rate" citizens inferior to the Tutsis (more frequently landowners), who considered themselves the rulers, following the European colonists who selected this group to be both privileged and educated. This situation exacerbated the tendency of the few to oppress the many, creating a 
legacy of hatred, resentment and tension that exploded into violence many times before and after the Hutu revolution (1959) and the independence (1962), henceforth reaching its climax in 1994.

But Diamond (2005) claims that the reality is quite different. He maintains that demographic growth had been about 3\% per year since the 1960s. In 1994, all arable land was exploited, the population density was 760 inhabitants per $\mathrm{km}^{2}$, as high as in England, and the food production, given the local agricultural practices, was insufficient to meet the needs. In 1985, the agricultural production per capita, after a continuous increase from 1966 to 1981, was back to the level of 1960. For Diamond, this food deficit was the cause of the genocide; as evidence, he states that in areas where there were few or no Tutsis, the Hutus killed Hutus. Of course there was an existing tribal rivalry, which was involved in the triggering of the genocide, but the real underlying cause was a food deficit. This hypothesis is confirmed by a booklet published before the genocide by Belgian agronomists (Wils et al. 1986), who said that a major food deficit crisis was bound to occur, but nothing had been done to prevent it. In Rwanda, the food deficit was not a water deficit, the country is very humid and does not lack water, it was an arable-land deficit. But the consequences are similar: food deficits can results in major conflicts.

Does climate variability (and water scarcity) play an important part in conflicts/violence, or is it expressing a modern form of environmental determinism? This is an ongoing debate (see e.g. Rahaman 2012; Hsiang and Burke 2014; Cane et al. 2014; Raleigh et al. 2014; Nordas and Gleditsch 2015; Buhaug 2015). Note that Wolf and coworkers at Oregon State University (see Wolf 1995; Subramanian et al. 2012; Kramer et al. 2013) have studied all the past water conflicts in the World, and developed a data base, the Transboundary Freshwater Dispute Database (TFDD, 2015) were all the disputes, conflicts and settlements have been documented. A map of the current 888 "hot spots" on the planet has been produced, see Wolf (2014). Based on the TFDD, De Stephano et al. (2012) have developed a map of potential future conflicts in the World in 2050 (Fig. 4). More than half of the basins at high risk are in Africa (Congo, Niger, Lake Chad), but other basins at risk exist in the Catatumbo basin between Columbia and Venezuela, in the Middle East, and in Eastern Europe, etc.

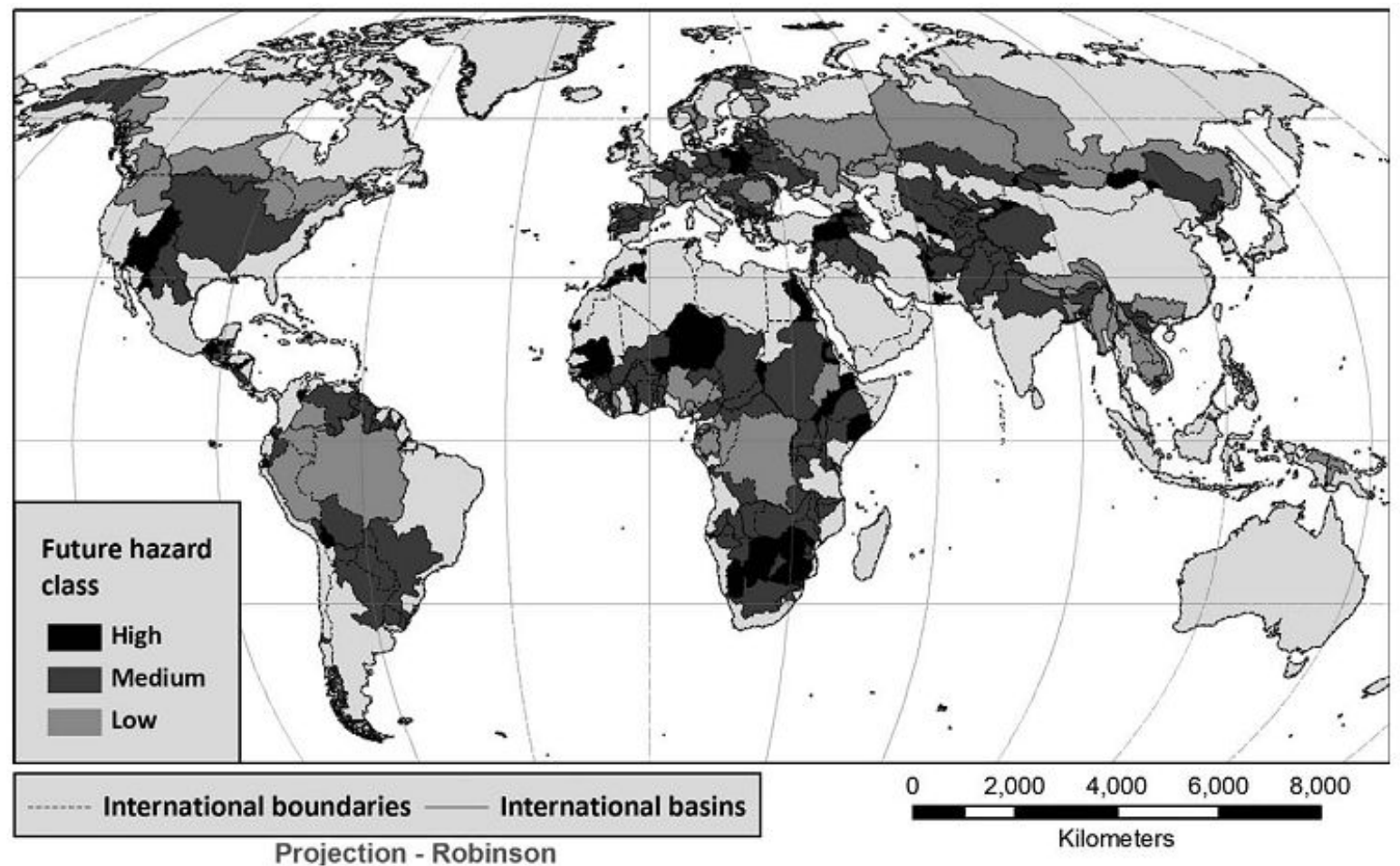

Fig. 4. Potential water-related conflicts in 2050 , with the intensity scale (high, medium, low) from De Stephano et al. (2012) 


\section{6.}

\section{Conclusions}

As predicted by the UN in 2012, the World population growth will put the planet under intense pressure to produce what will be needed to feed this population, with little place left for producing, at the same time, secondgeneration biofuels, and thus to solve the energy challenge. Contrary to current beliefs, water will not be the limiting factor of food production at the global scale: there is plenty of water on earth, mostly through the water-cycle, and in some places through the groundwater stocks. The major source of water to be used for food production is Green Water, i.e. rainwater infiltrated into the upper soil and available to the vegetation for evapotranspiration. The real limiting factor for food production is the availability of agricultural soils that can be farmed (excluding food grown artificially without soil, due to its very high costs).

The availability of water and soil is very unequally distributed on earth, compared to the distribution of the population. In other words, in many places on earth, the population growth will exceed the capacity of the countries to produce the food they need, as is already the case in some countries. The forecast for 2050 is that Asia (the continent as a whole) will not be able to feed itself due to a lack of arable land, and West-Asia-North-Africa even less so, due to a lack of water. Sub-Saharan Africa could have enough water and soils to feed itself, but if, and only if, intensive agricultural development takes place, mostly by increasing rain-fed agriculture and its yields, and developing irrigation. The food deficit in Asia and WANA (and in SS-Africa if the required development is not sufficient) will have to come from the three remaining zones: OECD countries, which need to increase their production (through irrigation, yield increase and new land farming), Russia and the CIS countries (mostly through yield increases), and lastly South America (through deforestation); all three zones will have to export "Virtual Water" to the countries with a food deficit. Sea transport of food is cheap and does not significantly harm the environment. In places where soils and water are available, but not in the same place (e.g. China, India, etc.), increasing irrigation by long-distance water transfers will be necessary to reduce the need for "Virtual Water" transfers.

For the countries that will need to import food, the real problem is to generate, by exports, the income required to pay for this import. It can be raw materials, e.g. minerals, oil or electric energy produced in arid zones, or industrial products, or services including tourism. It may happen that a country with water stress will be better off using the little water it has to produce goods or services rather than food, both in terms of economic and employment balance.

For countries with both arable land and water, which are obliged to increase their food production, two options are available: building dams and irrigation systems, or increasing the area of rain-fed agriculture, by deforestation. Both options have very negative consequences for the environment, the loss of natural ecosystems and biodiversity. Each situation may be different, and the two options need to be compared in each individual case, but irrigation is very efficient in reducing the surface area of land that needs to be farmed, since, on a global average, one hectare of irrigated land produces three times more food than one hectare of rain-fed land. But have we developed the tools and methodologies to compare the negative effects on the environment of each option, and to develop the best mitigation strategies to minimize these effects?

However, the World can sometimes experience very severe food deficits, both spatially and temporally, when the rains fail. In such situations, we have seen that tragic conflicts or genocide can happen. The monsoon zone seems to be the most fragile in that respect, with historical famines which had extremely severe death tolls, e.g. in the $19^{\text {th }}$ century, most likely linked to very strong El Niño events, lasting several years. Very intense volcanic eruptions can also have drastic effects on rainfall, temperature and global food production. The World is not protected against such food deficits, even if the last large famines occurred more than a hundred years ago. The only way to protect the 
World population against such events is to create stocks. However, economists do not favour food stocks, because of their costs, or consider them only as regulators of market prices. On March $6^{\text {th }}, 2015$, China indicated however that it would increase by $33 \%$ its budget for agricultural stocks, up to 24 billion dollars, or from 200 million tons to 250 (these are estimates, the exact numbers are state secrets). This looks as a very wise decision, and other countries should follow that route. But as hydrologists, we can offer an alternative: create water stocks. See for instance the immense social benefits that Egypt enjoyed with the construction of the Aswan dam: several episodes of droughts (and of floods) were prevented thanks to the dam, even if its environmental consequences were severe. No Egyptian would deny that. But how can we store water? We can build more dams, of course; the current volume of water stored in dams is about $8500 \mathrm{~km}^{3}$ (Chao et al. 2008), and it could be increased, notwithstanding their environmental consequences.

But there is a better alternative: storing water underground in aquifers. The volume of water naturally stored in aquifers is huge: 15 million $\mathrm{km}^{3}$. There is room for water storage in aquifers equal to 600,000 times the current amount of water stored in dams! Artificial recharge of aquifers has been tested in many places (see e.g. Dillon et al. 2009) and can be implemented relatively easily. In drought-prone areas, the aquifers should be recharged artificially in order to store water for "bad times", instead of being depleted as is currently the case. In areas where the aquifers are brackish, it is possible to inject freshwater and create "lenses" of fresh water within the brackish aquifer, where mixing would occur only at the interfaces.

This should be the major task of the next generation of hydrologists: take good-quality surface water from rivers, when there is plenty, treat it, and store it underground (where it does not evaporate) in aquifers, to provide water and food in case of drought. Tools such as GRACE satellite mission can be an efficient way to monitor the global amount of water stored on earth.

\section{Acknowledgments}

The authors wish to thank the two reviewers, Prof. M. Besbes and one anonymous colleague, for their help in correcting and improving this article; they also wish to express their gratitude to the Guest Editor of this issue, Dr. Anny Cazenave, for her invitation to prepare this paper together, and for organizing the reviewing and final editing of this work.

\section{References}

Académie des Sciences (2006). Les Eaux Continentales, coordinated by Marsily G de. EDP Sciences, Paris, France.

Académie des Sciences (2011). Démographie, Climat et Alimentation Mondiale, coordinated by Leridon H and Marsily G de. EDP Sciences, Paris, France.

Agrimonde (2010) Scénarios et défis pour nourrir le monde en 2050. Coordinated by Paillard S, Treyer S, Dorin B. Quae, Versailles, France

Allan JA (1998) Moving water to satisfy uneven global needs. Trading water as an alternative to engineering it. ICID Journal, 47(2):1-8.

Azmeh S (2014), The Uprising of the Marginalised: A Socio-Economic Perspective of the Syrian uprising, LSE Middle East Centre Paper Series 06, 28 p, (available at http://eprints.lse.ac.uk/60243/)

Baraer M, Mark B, McKenzie J, Condom T, Bury J, Huh K, Portocarrero C, Gomez J, Rathay S (2012) Glacier recession and water resources in Peru's Cordillera Blanca. Journal of Glaciology, 58(207): 134-150.

Besbes M, Chahed J, Hamdane A, Marsily G de (2009) Water resources assessment and food production in 
arid zones : the example of Tunisia with a global change context. In: Courel MF, Schneider-Madanes G (eds) Water ecosystems and sustainable development in arid and semi-arid zones. Springer, Berlin.

Besbes M, Chahed J, Hamdane A (2014) Sécurité Hydrique de la Tunisie, gérer l'eau en conditions de pénurie. L'Harmattan, Paris.

Bradley R, Vuille M, Diaz H, Vergara W (2006) Threats to Water Supplies in the Tropical Andes. Science, 312: $1755-1756$.

Buhaug H (2015) Climate-conflict research: some reflections on the way forward. WIREs Clim Change. doi: $10.1002 /$ wcc. 336

Cai W, Borlace S, Lengaigne M, Rensch PV, Collins M, Vecchi G, Timmermann A, Santoso A, McPhaden MJ, Wu L, England MH, Wang G, Guilyardi E, Jin FF (2014). Increasing Frequency of Extreme El Niño Events Due to Greenhouse Warming. Nature Climate Change, 4(2), pp. 111-116. doi:10.1038/nclimate2100

Cane MA, Miguel E, Burke M, Hsiang SM, Lobell DB, Meng KC, Satyanath S (2014) Temperature and violence, Nature Clim. Change, 4: 234-235, doi:10.1038/nclimate2171

Chahed J, Hamdane A, Besbes M (2008) A comprehensive water balance of Tunisia : blue water, green water and virtual water. Water International, 33:4.

Chao BF, Wu YH, Li YS (2008) Impact of artificial reservoir water impoundment on global sea level. Sciencexpress 1-3, www.sciencexpress.org. doi:10.1126/science.1154580

Chevallier P, Pouyaud B, Suarez W, Condom T (2011) Climate change threats to environment in the tropical Andes: glaciers and water resources. Supplement to Regional Environmental Change, 11(1): 179 -187.

Cook ER (2013) Megadroughts, ENSO, and the Invasion of Late-Roman Europe by the Huns and Avars, In: Harris WV (ed) The Ancient Mediterranean Environment between Sciences and History. Leiden-Boston, Brill, pp 103-170. ISBN: 978-90-04-25343-8

Dai A (2013) Increasing drought under global warming in observations and models. Nature Climate Change, 3: 52-58. doi:10.1038/nclimate1633

Dalin C, Konar M, Hanasaki N, Rinaldo A, Rodriguez-Iturbe I (2012) Evolution of the global virtual water trade network. Proc Nat Acad Sci PNAS 109(16). www.pnas.org/cgi/doi/10.1073/pnas.1203176109

Davies BJ, Glasser NF (2012) Accelerating recession in Patagonian glaciers from the "Little Ice Age" (c. A.D. 1870) to 2011. Journal of Glaciology 58 (212), 1063-1084.

Davis M (2001) Late Victorian Holocausts, El Niñ Famines and the Making of the Third World, Verso, London. ISBN: 1-85984-739-0

De Stefano L, Duncan J, Dinar S, Stahl K, Strzepek K, Wolf AT (2012) Climate change and the institutional resilience of international river basins. J Peace Res 49(1):193-209

Demarest A (2004) Ancient Maya. The rise and fall of a Rainforest Civilization. Cambridge University Press. ISBN: 13-9780521592246

Denommee KC, Bentley SJ, Droxler AW (2014) Climatic controls on hurricane patterns: a 1200-y nearannual record from Lighthouse Reef, Belize. Nat Sci Rep 4:3876. doi:10.1038/srep03876.

Diamond J (2005) Collapse. How societies choose to fail or succeed. Viking Penguins, New-York. ISBN-13: 978-0670033379.

Diaz HF, Bradley RS, Ning L (2014) Climatic changes in mountain regions of the American Cordillera and the Tropics: historical changes and future outlook. Arct Antarct Alp Res 46(4):1-9.

Dillon P, Gale I, Contreras S, Pavelic P, Evans R, Ward (2009) Managing aquifer recharge and discharge to sustain irrigation livelihoods under water scarcity and climate change. In: Bl?schl G, van de Giesen N, Muralidharan D, Ren L, Seyler F, Sharma U, Vrba J (eds) Improving integrated surface and groundwater resources management in a vulnerable and changing world. IAHS Publishers, 330, IAHS, Wallingford, pp 1-12.

Döll P, Müller Schmied H,, Schuh C, Portman FT, Eicker A (2014) Global-scale assessment of groundwaterdepletion and related groundwater abstractions: combining hydrological modeling with information from well observations and GRACE satellites. Water Resour Res. doi:10.1002/2014WR015595. 
Döll P, Douville H, Güntner A, Müller Schmied H, Wada (2015) Modelling the continental water cycle: challenges and prospects. Remote Sensing and Water Resources. In: ISSI Workshop. To appear, Survey in Geophysics, this volume.

FAO Food and Agriculture Organization (2002) World agriculture : Towards 2030-2050. FAO, Rome http://www.fao.org./docrep/004/Y3557E/y3557e00.HTM

FAO Food and Agriculture Organization (2003) World agriculture : Towards 2015-2030. FAO, Rome http://www.fao.org/fileadmin/user_upload/esag/docs/y4252e.pdf

FAO Food and Agriculture Organization (2006) World agriculture : Towards 2030-2050 (Interim report).

FAO, Rome, ftp://ftp.fao.org/docrep/fao/009/a0607e/a0607e00.pdf

FAO Food and Agricultural Organization (2012) Energy-smart food at FAO; an overview.

http://www.fao.org/3/a-an913e.pdf

FAO Food and Agricultural Organization (2014) Hunger map.

http://www.fao.org/fileadmin/templates/ess/foodsecurity/poster_web_001_WFS.jpg

FAO Food and Agricultural Organzation (2015a) World Food Situation, Cereals Supply and Demand Brief,

March 5, 2015, http://www.fao.org/worldfoodsituation/csdb/en/

FAO Food and Agricultural Organization (2015b) The contribution of insects to food security, livelihood and the environment, http://www.fao.org/forestry/edibleinsects/en/

Gerland P, Raftery AE, Ševčíková H, Li N, Gu D, Spoorenberg T, Alkema L, Fosdick BK, Chunn J, Lalic N, Bay G, Buettner T, Heilig GK, Wilmoth J (2014) World population stabilization unlikely this century. Science, 346:, 234-237, doi: 10.1126/science. 1257469

Gleick PH (2014) Water, Drought, Climate Change, and Conflict in Syria. Wea. Climate Soc., 6:331340.doi: http://dx.doi.org/10.1175/WCAS-D-13-00059.1

Griffon M (2006) Nourrir la planète. Ed. Odile Jacob, Paris, France.

Hodell DA, Curtis JH, Brenner M (1995) Possible role of climate in the collapse of Classic maya civilization. Nature 375:391-394. doi:10.1038/375391a0

Hoekstra AY, Chapagain AK, Aldaya MM, Mekonnen MM (2011) The water footprint assessment manual: Setting the global standard. Earthscan London, ISBN: 978-1-84971-279-8,.

Hoekstra AY, Mekonnen MM (2012) The water footprint of humanity. PNAS, 109. 3232-3237, doi: 10.1073/pnas.1109936109

Holdridge LR (1967) Life Zone Ecology, Tropical Science Center, San José (Costa Rica). 206 p.

Hsiang SM, Burke M (2014) Climate, conflict, and social stability: what does the evidence say? Clim. Change 123: 39-55. doi:10.1007/s10584-013-0868-3.

IPCC (2014) Fifth Assessment Report. Intergovernmental Panel on Climate Change, Geneva, Switzerland.

IWMI (2007) Water for Food, Water for Life : the Comprehensive Assessment of Water Management in Agriculture, Molden D (ed) International Water Management Institute, Colombo, Sri Lanka. Earthscan, London.

Kaniewski D, Van Campo E, Guiot J, Le Burel S, Otto T, et al (2013) Environmental roots of the late bronze age crisis. PLoS One. 8(8):e71004. doi: 10.1371/journal.pone.0071004

Kelley CP, Mohtadi S, Cane MK, Seager R, Kushnir Y (2015) Climate change in the Fertile Crescent and implications of the recent Syrian drought. PNAS. doi : 10.1073/pnas. 1421533112

Kennett D J, Breitenbach SFM, Aquino VV, Asmerom Y et al. (2012) Development and Disintegration of Maya Political Systems in Response to Climate Change. Science, 338(6108): 788-791. doi: 10.1126/science.1226299.

Konikow LF (2011) Contribution of global groundwater depletion since 1900 to sea-level rise. Geophys. Res. Letters, 38: 17. doi: 10.1029/2011GL048604

Kramer A, Wolf AT, Carius A, Dabeklo GD (2013) The key to managing conflict and cooperation over water. A World of Science, 11, 1.

Leemans R (1992) Global Holdridge Life Zone Classifications, in Global Ecosystems Database Version 2.0, NOAA National Geophysical Data Center, Boulder, CO, USA. 
LizumiT, Luo J, Challinor A, Sakurai G, Yokozawa M, Sakuma H, Brown M, Yamagata T (2014) Impacts of El Niño southern oscillation on the global yields of major crops. Nature Communication, 5: 3712. doi: 10.1038/ncomms4712.

Makkar HPS, Tran G, Henze V et al. (2014) State-of-the-art on use of insects as animal feed. Animal Feed Sciences and Technology, 197: 1-33.

Manning SW (2013) The Roman world and climate: context, relevance of climate change, and some issues.

In: Harris WV (ed) The Ancient Mediterranean environment between sciences and history. pp 103-170. LeidenBoston: Brill. ISBN: 978-90-04-25343-8

Marsily G de (2007) An overview of the world's water resources problems in 2050, Ecohydrology and Hydrobiology, 7(2): 147-155.

Marsily G de (2009) L'eau, un trésor en partage. Dunod, Paris, 256 p.

Masson MA (2012) Maya collapse cycles, PNAS, 109(45): 18237-18238, doi: 10.1073/pnas.1213638109.

Millennium Ecosystem Assessment (2005) Ecosystems and human well-being: synthesis. Washington, DC: Island Press. ISBN 1-59726-040-1.

Mithen SJ (2012) Thirst : Water and Power in the Ancient World, Weidenfeld \& Nicolson, London, 346 pp, ISBN 978-0-674-06693-6 .

Moya Quiroga V, Mano A, Asaoka Y, Udo K, Kure S, Mendoza J (2014) Estimation of Glacier Melt Water Contribution for Human Consumption in the Royal Andes Considering Temperature Measurement Errors, Open Journal of Modern Hydrology, 2014, 4, 27-43

Musy A, Higy C (2010) Hydrology: A Science of Nature, CRC Press 346p , ISBN 9781578087099 - CAT\# N10334

Nicholson L, Marin J, Lopez D, Rabatel A, Brown F, Rivera A (2009) Glacier inventory of the upper Huasco valley, Norte Chico, Chile: glacier characteristics, glacier change and comparison with central Chile. Annals of Glaciology 50(53):111 - 118 .

Nordas R, Gleditsch NP (2015) Climate change and conflict. In: Hartard S, Lieber W (eds) Competition and conflicts on resource use. Natural Resources Management and Policy, 46:21-38. doi:10.1007/978-3-319-10954-1_3

Ortlieb L (2000) The documented historical period of El Niño events in Peru: an update of the Quinn record (16th to 19th centuries). In: Diaz HF, Markgraf V (eds) El Niño and the southern oscillation. Multiscale variability and local and regional impacts. Cambridge University Press, Cambridge, pp 207-295.

Post VEA, Groen J, Kooi H, Person M, Ge S, Edmunds WM (2013), Offshore fresh groundwater reserves as a global phenomenon. Nature 504(5):12. doi:10.1038/nature12858

Rabatel A, Francou B, Soruco A, Gomez J, Caceres B, et al. (2013) Current state of glaciers in the tropical Andes: a multi-century perspective on glacier evolution and climate change. The Cryosphere 7(1): 81-102.

Rahaman MM (2012) Water Wars in 21st Century: Speculation or Reality? International Journal of Sustainable Society, 4: 3-10.

Raleigh C, Linke A, O'Loughlin J (2014) Extreme temperatures and violence, Nature Clim. Change 4:76-77..

Ramirez E, Olmos C, Romàn J (2007) Deshielo de la cuenca Tuni Condoriri y su impacto sobre los recursos hídricos de las ciudades de La Paz y El Alto. Ed. P. Quinquenal. La Paz, Bolivia: GRANT - GREAT ICE, IHH-IRD.

Renault D, Wallender WW (2000) Nutritional water productivity and diets: From crop per drop towards nutrition per drop. Agricultural Water Management, 45:275-296.

Rijsberman FR (2006), Water scarcity: Fact or fiction?, Agricultural Water Management, 80(1-3): 5-22.

Rockström J (2004), Magnitude of the hunger alleviation challenge - Implications for consumptive use. Stockholm International Water Institute, Balancing food and environmental security. Finding opportunities for improving livelihoods. Stockholm.

Rojas O, Li Y, Cumani R (2014) Understanding the drought impact of El Niño on the global agricultural areas: An assessment using FAO's Agricultural Stress Index (ASI), FAO, Climate, energy and tenure division (nRc) publications, 52 pp. ISBN: 978-92-5-108671-1, ISSN: 2071-0992.

Rumpold BA, Schlueter OK (2013) Nutritional composition and safety aspects of edible insects. Molecular Nutrition \& Food Research, 57:141-160. 
Sen A, Drèze J (1999) Omnibus. Oxford University Press, New Delhi, India. ISBN: 13:978-0195648317.

Sheffield J, Wood EF (2011) Drought: Past Problems and Future Scenarios, Earthscan, , UK, ISBN: 13-9781849710824, $192 \mathrm{p}$.

Sheffield J, Wood EF, Roderick ML (2012) Little change in global drought over the past 60 years. Nature, 491: 435-438. doi:10.1038/nature11575.

Shelton LM (2009) Hydroclimatology: Perspectives and Applications, Cambridge University Press, p 418.

Shiklomanov IA (1999) World freshwater resources and their Use. Database on CD Rom. UNESCO, Paris.

Shiklomanov IA, Rodda JC (2003) [Eds] World Water Resources at the Beginning of the Twenty-first Century. Cambridge University Press, Cambridge, UK.

SIWI (2008) Stockholm International Water Institute. Saving water: From Field to Fork. Cutting losses and Wastage in the Food Chain. Stockholm.

Soruco A (2012) Medio siglo de fluctuaciones glaciares en la Cordillera Real, y su efectos hidrológicos en la ciudad de La Paz. IRD, La Paz, ISBN: 978-99954-55-62-, pp. 228.

Subramanian A, Brown B, Wolf A (2012) Reaching across the waters: Facing the risks of cooperation in international waters. Washington DC: The World Bank Press.

Tardieu F (2005) Plant tolerance to water deficit: physical limits and possibilities for progress. In: Académie des Sciences, Comptes Rendus Geoscience, 337: 57-67.

TFDD (2015) Transboundary Freshwater Dispute Database, International Freshwater Treaty Database,

Oregon State University. http://www.transboundarywaters.orst.edu/database/interfreshtreatdata.html

Trenberth KE, Smith L, Qian T, Dai A, Fasulo J (2007) Estimates of the global water budget and its annual cycle using observational and model data. J. of Hydrometeorology, Special Section, 8:758-769.

Trenberth KE, Dai A, van der Schrier G, Jones PD, Barichivich J, Briffa KR, Sheffield J (2014) Global warming and changes in drought. Nat. Clim. Change 4: 17-22.

Turner BL, Sabloff JA (2012), Classic period collapse of the Central Maya Lowlands: insights about human-environment relationships for sustainability. Proc Natl Acad Sci USA 109(35): 13908-13914.

doi:10.1073/pnas.1210106109

Vicente-Serrano SM, López-Moreno JI, Gimeno L, Nieto R, Morán-Tejeda E, Lorenzo-Lacruz J, Beguería S, Azorin-Molina C (2011) A multiscalar global evaluation of the impact of ENSO on droughts, J. Geophys. Res., 116, D20109. doi:10.1029/2011JD016039.

Viviroli D, Dürr HH, Meybeck M, Weingartner R, Messerli B (2007) Mountains of the world —water towers

for humanity: typology, mapping and global significance. Water Resour Res 43:W07447. doi:10.1029/2006WR005663

Vuille M, Francou B, Wagnon P, Irmgard J, Kaser G, Mark B, Bradley R (2008) Climate change and tropical Andean glaciers: Past, present and future. Earth Science Reviews. 89:_79-96.

Vuille M (2013) Climate Change and water resources in the tropical Andes, Interamerican Development Bank Technical Note, No. IDB-TN-515.

Wada Y, Van Beek LPH, Bierkens MFP (2012) Non-sustainable groundwater sustaining irrigation : a global assessment. Water Resources Research, Vol. 48, doi:10.1029/2011WR010562.

Welzer H (2012) Climate Wars: What People Will Be Killed For in the 21st Century, Wiley, 288p. ISBN: 978-0-7456-5145-3.

Willis M, Melkonian A, Pritchard M, Rivera A. (2012) Ice loss from the Southern Patagonian Ice Field, South America, between 2000 and 2012. Geophysical Research Letters 29(L17501). doi:10.1029/2012GL053136.

Wils W, Carael M, Tondeur G (1986) Le Kivu Montagneux: surpopulation, sous-nutrition, érosion du sol. Mem. Acad. Royale Sc.Outremer Belgique, tome 21, fasc.n 3.

Wolf A (1995) Hydropolitics along the Jordan River: The impact of scarce water resources on the ArabIsraeli conflict. Tokyo and New York: United Nations University Press, 1995-

Wolf A (2014) Where Will the World's water Conflicts Erupt? A heatmap of war over water. Edited by Katie Peek, Popular Science, Posted June 13, 2014. http://www.popsci.com/article/science/where-will-worlds-waterconflicts-erupt-infographic. 
WWAP (2012) United Nations Educational, Scientific and Cultural Organization (UNESCO), United Nations World Water Assessment Programme (WWAP), UN-Water. March 2012; see also World Resources Institute at : http://www.wri.org/resource/physical-and-economic-water-scarcity.

WWDR (2012) Managing Water under Uncertainty and Risk, in $4^{\text {th }}$ edition of the UN World Water Development Report (WWDR4), World Water Assessment Programme (WWAP), 909 p.

Zimmer D (2013) L'empreinte eau. Les faces cachées d'une ressource vitale. Charles Léopold Meyer, Paris. 